\title{
Antipodean American Literary Studies: An Interview with Paul Giles
}

\section{Thomas Constantinesco and Paul Giles}

\section{(2) OpenEdition \\ 1 Journals}

\section{Electronic version}

URL: https://journals.openedition.org/transatlantica/17470

DOI: 10.4000/transatlantica. 17470

ISSN: 1765-2766

\section{Publisher}

Association française d'Etudes Américaines (AFEA)

\section{Electronic reference}

Thomas Constantinesco and Paul Giles, "Antipodean American Literary Studies: An Interview with Paul Giles", Transatlantica [Online], Hors-série | 2021, Online since 01 October 2021, connection on 11 October 2021. URL: http://journals.openedition.org/transatlantica/17470 ; DOI: https://doi.org/ 10.4000/transatlantica. 17470

This text was automatically generated on 11 October 2021

\section{c) (i)}

Transatlantica - Revue d'études américaines est mise à disposition selon les termes de la licence Creative Commons Attribution - Pas d'Utilisation Commerciale - Pas de Modification 4.0 International. 


\title{
Antipodean American Literary Studies: An Interview with Paul Giles
}

\author{
Thomas Constantinesco and Paul Giles
}

Paul Giles is Challis Professor of English at the University of Sydney, Australia. He is the author of many books discussing English, American, and Australian literature from transnational perspectives, including American Catholic Arts and Fictions: Culture, Ideology, Aesthetics (Cambridge University Press, 1992), Virtual Americas: Transnational Fictions and the Transatlantic Imaginary (Duke University Press, 2002), The Global Remapping of American Literature (Princeton University Press, 2011), Antipodean America: Australasia and the Constitution of U.S. Literature (Oxford University Press, 2013). He was previously President of the International American Studies Association (2005-2007) and Director of the Rothermere American Institute at Oxford University (2003-2008). He is currently serving as president of the International Association of University Professors of English and completing a trilogy of books on cultural representations of antipodean time, of which the first two volumes have recently been published: Backgazing: Reverse Time in Modernist Culture (Oxford University Press, 2019) and The Planetary Clock: Antipodean Time and Spherical Postmodern Fictions (Oxford University Press, 2021). 


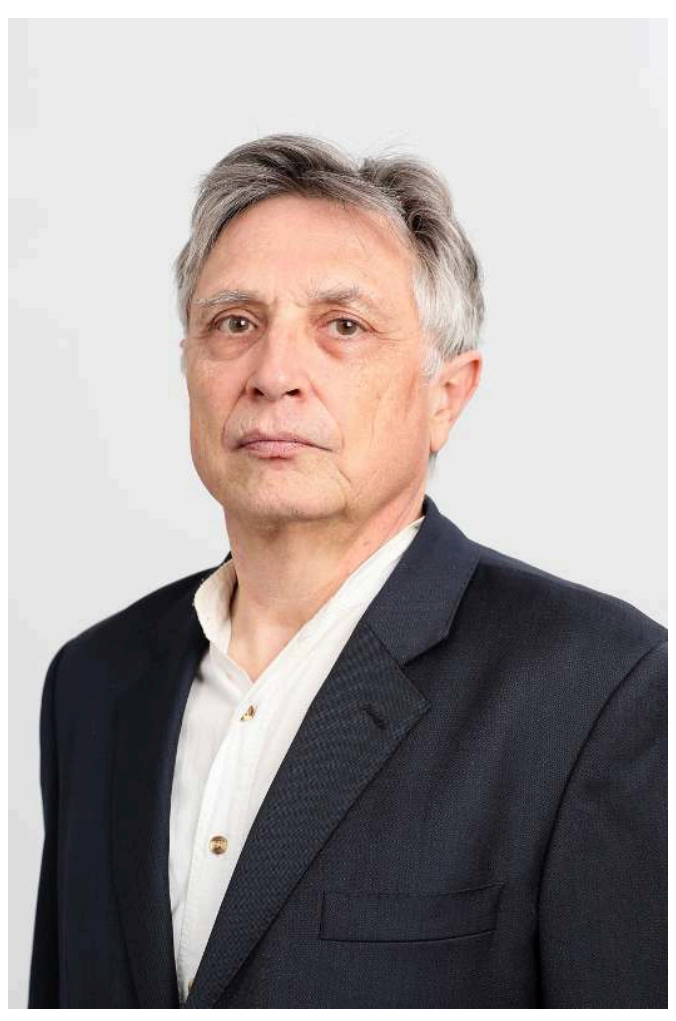

Thomas constantinesco: From Transatlantic Insurrections (2001) and Virtual Americas (2002) to The Global Remapping of American Literature (2011), Antipodean America (2013) and, recently, The Planetary Clock: Antipodean Time and Spherical Postmodern Fictions (2021), your work has focused in part on mapping the spatial coordinates of American literature, while seeking to expand the hermeneutic scales through which we read it: from transatlantic relations, to transnational fictions, to World American literature, to planetary imagination. Could you tell us more about these expanding scales, how they intersect, overlap, or problematize one another and how you see them framing the critical field of American literary studies?

Paul Giles: I think I would actually trace this pattern back further, to my first book, Hart Crane: The Contexts of The Bridge (1986), and my second, American Catholic Arts and Fictions: Culture, Ideology, Aesthetics (1992). The Crane book, based on my D.Phil. at Oxford in the early 1980s, was an attempt to resituate a poet who had been critically understood almost exclusively in nationalist terms (as a kind of son of Whitman) in relation to the other kinds of cultural forces he was negotiating. I was particularly interested in Crane's engagement with the surrealism coming out of Paris in the 1920s and James Joyce's experiments with language in "Work in Progress," then being serialized in the Paris magazine transition before subsequently appearing as Finnegans Wake. (Crane himself visited Paris in 1929.) This thesis was controversial at the time because it seemed to go against the grain of what was understood rather rigidly in those "myth and symbol" days as the nationalist imperatives of American literature, but looking back I think it was my first flirtation with a transnational approach, although I did not of course conceive of the project so self-consciously at that time. ${ }^{2}$

I graduated at the height of the Thatcher years in England, when there were almost no academic jobs in literary studies, and I was fortunate to be offered in 1987 a tenure-track position at Portland State University in Oregon. There I had the interesting experience of teaching American literature to American students who had imbibed received ideas about the national canon from their high school 
education onwards, and I enjoyed challenging some of their preconceptions, although they also taught me a lot about ways in which various aspects of the national imaginary had become embedded in students' consciousness. I remember one sophomore complaining to the Dean about a class in Early American Literature where I had been discussing the poetry of Edward Taylor and suggesting that his English upbringing and heritage were just as important to his work as his commitment to New England Puritanism in the 1660s. This was, I think, a crucial formative time for me intellectually, and I wrote most of the American Catholic Arts and Fictions book in Oregon, deliberately seeking an alternative genealogy for American literature rather than the classic forms of Puritanism that had, until then, tended to dominate the field of American literary scholarship, from Perry Miller to Sacvan Bercovitch.

I think that my subsequent transatlantic trilogy-Transatlantic Insurrections, Virtual Americas and Atlantic Republic (2006)-bore quite a close intellectual relation to the Catholic book, since the latter was interested in tracing how certain forms (fictions) of universalism intersected in uncomfortable ways with US national agendas. I was interested in theology not as a metaphysical but as a cultural phenomenon, and in suggesting how various writers and film-makers-Dreiser, Mary McCarthy, Scorsese and many others-were invested not in any specific nationalist project but in the ways universalist designs ("catholicity") manifested themselves within local circumstances. Their primary allegiance, in other words, was not to any national jurisdiction as such, but to a transnational style that could sometimes be linked to alternative ethnic homelands (Coppola's representation of Italy in the Godfather films, for example) or to moral questions that exceeded the legislative remit of any civil authority (such as we see all the time in Flannery O'Connor). It was not such a big step from there to interrogate some of the mythical preconceptions associated with the American Revolution in Transatlantic Insurrections by suggesting how the events of 1776 arose from intellectual as well as political division in the British Empire, so that both English and American literature of that era could only properly be understood in relation to each other. Virtual Americas continued this argument into the later Victorian and modern periods, suggesting how overseas influences had impacted upon understandings of classic American authors. This was of course an emerging concern in much Americanist scholarship of the 1990s, in the work of Paul Gilroy and others, but Virtual Americas gave the theme a different spin by relating it to the new models of communications technology then being developed that were also quickly changing ways in which space was conceptualized and archival memories accessed. Atlantic Republic was more about how the English literary canon has always been intricately interwoven with transatlantic ideas and American horizons, while The Global Remapping of American Literature and then Antipodean America were attempts to expand the circumference of American literary studies beyond merely a European compass.

Obviously there are always limitations inherent in any attempt to think of American literature in "global" terms, and the aim in these works was not to be allencompassing, but rather to think about some of the differences that emerge when American literature is read from other terrestrial perspectives. One of the things that has always irritated me about more traditional forms of Americanist scholarship is the way they imagine they are recognizing alterity by simply addressing it from a domestic standpoint, by incorporating the world from a secure US base, rather than 
considering the significant ways in which assumptions and agendas are changed when points on the compass are reversed. This is the problem with hundreds of programs in "Global Studies" in US institutions, although there is some American scholarship that is much more sensitive to linguistic and cultural difference, that of Brian T. Edwards for example.

T.c.: You mentioned how Virtual Americas was part of a larger conversation about transatlantic spaces and circuits of influences that took hold of Americanist scholarship in the 1990s and early 2000s. Your more recent work on time may also be seen as part of the larger "temporal turn" that has been animating Americanist scholarship. I am thinking of Lloyd Pratt's Archives of American Time (2010), but also Cindy Weinstein's Time, Tense, and American Literature: When Is Now? (2015), as well as her edited collection, A Question of Time: American Literature from Colonial Encounters to Contemporary Fiction (2018), to name only a few titles. Could you elaborate on your relation to these various, sometimes overlapping "turns"?

P.G.: Yes, there has been very interesting work in relation to temporality, such as Wai Chee Dimock's work on deep time, or Dana Luciano's study of how notions of ecology influence representations of time in literature, in addition to the titles you mention. But these works usually address questions of time in a specific historical period, say the nineteenth century or the modern period. My own project is different because it is coming at the question of temporality from a specific geographical perspective, an antipodean perspective, as I am trying to integrate a rather different way of thinking about time and space by positioning myself on a different point on the planetary compass, as it were.

I also try not to be circumscribed within one particular framework. There is always a danger with the very idea of scholarly turns, in that they can become a bit of a bandwagon. The more enduring works, like Bernard Smith's work on art history and the Antipodes for instance, try to take critical fashions and use them in a wider conceptual space. I want to draw links among different geographical areas as well as across different historical eras. Dimock's Through Other Continents, to take one example, is mainly focused on the modern and contemporary periods, whereas I think there is a case to be made for trying to draw connections across a much broader temporal horizon, even going back to the eighteenth century or the Renaissance. These connections are difficult to make in a scholarly sense because they are unusual and scholars tend to focus on their own period of specialization. But if they are done creatively, they may possibly open up alternative points of view on literary works.

T.c.: I would like to press on your investment in the mutually constitutive relation between time and space. You show not only how time and space are far from homogeneous on their own terms, but also how they problematize each other. This resonates uncannily with the way the current pandemic has been unsettling our relation to space and time. In a recent forum of American Literature, Robert Peckham wrote of the "temporal entanglements" made visible by Covid-19 and on the fundamental "heterotemporality" of pandemic time. But these entanglements are also spatial, as global disruptions collide with national and local situations. How are the categories that you have been deploying pertinent for thinking about the situation we find ourselves in at this juncture?

P.G.: Certainly, the pandemic of Covid-19 is likely to constitute a major area of scholarly interest for many years to come. It may well be the next turn, as a matter of fact. I might point here to an essay I was asked to contribute to a forthcoming issue of American Literary History where I look at how plague has been represented in 
American literature, going back to Brockden Brown's Arthur Mervyn (1799) and that novel's examination of an epidemic outbreak in Philadelphia in the late eighteenth century through contagious diseases coming from the West Indies. One of the things that interested Brown was how the experience of an interconnected world, where commodities and ideas were flowing in many different directions, was very different from the Republican version of America, where, as Jefferson hoped and anticipated, an "ocean of fire" would separate America from Europe (Jefferson 1044). On this account, the larger legacy of Brown's Federalist sympathies may not have been properly appreciated in scholarly terms. More generally, I believe that the idea of an interconnected world has been largely missing from Americanist scholarship, where the metaphor of the "city on a hill"-America as a beacon-has continued to be privileged, from the Transcendentalists through to the Civil Rights Era and beyond. In this respect, the Covid-19 pandemic is likely to lead to a reassessment, not just of the contemporary period, but also of earlier eras as well.

In the foreword to The Planetary Clock, I acknowledge the onset of the pandemic, which occurred as the book came out. If I were to look back on it in ten years' time, I might venture to say that postmodernism has ended with Covid. If one thinks of a long modernism, from 1890 to 1960, one could similarly think of a long postmodernism from about 1960 to 2020 .

T.c.: Since you mention The Planetary Clock, I want to ask about two of the key terms you elaborate there: the antipodean and the spherical, which become critical concepts to approach the aesthetics, the ethics, and the politics of postmodernism. How are we to understand these notions; how are they related; and how may they be brought to bear on the study of cultural productions?

On a pedagogical note, you have been a Professor of English at the University of Sydney since 2010: what does it mean to teach American literature from an antipodean perspective? And how does it compare to teaching American literature in a UK context, since you also held appointments at Nottingham, Cambridge, and Oxford?

P.G.: I see antipodean and spherical as both relational terms that effectively interrogate more parochial definitions of postmodernism as a product merely of US consumer culture. I take issue in the book with US-centric definitions of postmodernism that have, I think, held sway for far too long. Stuart Hall suggested in 1986 that postmodernism was "about how the world dreams itself to be "American" (Grossberg 46), but I argue that it was always a more complex and varied phenomenon than that.

In Australia I've taught an undergraduate class entitled "Global America," which discusses how American cultural narratives circulate globally. It's interesting to see how many of the students in Sydney don't distinguish clearly between their own domestic sphere and US cultural capital-they see iPhones and Netflix series set in California as part of their own everyday lives, and this clearly implies how "America" is now a global sign rather than just a local, national or distant entity. At the same time, the crossovers and tensions between domestic elements and transnational pressures are often particularly illuminating, indicating the kinds of convergence and divergence that allow the limits and limitations of any national culture to come into focus. Australian culture is a mixture of many different influences-British colonialism, but also a long tradition of socialist collectivism, as well as enduring Indigenous cultures-and this means it's perhaps more difficult and challenging to categorize Australian relations to America. As Gayatri Spivak remarked back in 1984, 
"the place of Australia on the (world) map is so problematic" that it has the effect of "shaking that structure up" (Grosz 187) When I was working in Europe, I found there often tended to be a certain romanticization of US values, perhaps growing out of how American Studies programmes developed so quickly in the years after World War II, which meant that issues such as Civil Rights and Beat writing tended to be glamorized, with the inherent conservatism of the US body politic consistently underplayed. Perhaps this has changed now, after the Trump years, but I think it's possible that approaching the constitutionally liberal US domain from a less rigidly defined space opens up different kinds of questions about how America relates to the rest of the world.

T.c.: To come at the critical purchase of "the antipodean" and "the spherical" from perhaps another angle: one of the arguments you put forward in The Planetary Clock is that we need to understand environmental issues such as climate change, not in opposition, but in relation to what you call, following Baudrillard, "virtual reality" (19). Could you tell us more? Could you also address the way your book sits within Environmental Humanities scholarship?

You further bring the notions of "virtuality" and "virtual geography" (364) to bear not just on American and American literature-the way you did for instance in Virtual Americas-but on a planetary scale. In your work more generally, I take the virtual to be linked to the disruptive potential of the queer and to the unruly force of irony as modes of challenging the normative. How does "the virtual" stand in relation to "the antipodean," queerness and irony?

P.G.: My point in the book is that predictions of climate change are intricately interwoven with computer-generated models, and this makes the interface between literal and virtual reality more permeable than is sometimes imagined. The emergence of climate change as a political issue has been framed in every way by postmodernist templates. My goal in The Planetary Clock was to suggest how environmental issues are a crucial and in some ways defining concern of a spherical postmodernism, rather than just a Western postmodernism fixated on the depredations of American consumer capitalism.

On the virtual, yes, I think, that's an interesting point about how it seems to be linked intellectually to forms of disruptive queerness and irony. I suppose the virtual introduces a certain idea of critical distance, which is linked to information technology but not synonymous with it. The antipodean again operates as a form of strategic distance, bringing different planetary conditions into juxtaposition. Just as transnationalism as a critical method was useful in bringing different national formations into provocative juxtaposition, so the antipodean uses geography to open up broader questions about dislocation and displacement. There are other ways of linking critical discourse to geographical materialism, of course. Édouard Glissant, for example, used what he called "Antillean discourse" to open up larger questions about imperial power and centrifugal circulation that arose out of, but were not confined to, a particular geographic space.

T.c.: Alongside its theoretical interventions, The Planetary Clock is also pursuing a methodological agenda, which already informs your previous books. On the one hand, you attempt to "balance detailed readings of particular authors with discussions of more general cultural formations" (59), in order to bring out the ways in which literary texts are embedded in a larger culture, as well as how they contribute to shaping and critiquing it. On the other hand, your readings perform crossovers between artistic forms and genres, linking literature with music and the visual arts. How may this enable us to argue for "the 
singularity of literature," as Derek Attridge might say, and for the specificity of literary studies? Or would you rather consider yourself as a cultural critic? And in that case, what would it mean for the disciplinarity of literary studies?

P.G.: I don't think my work fits very neatly into any category. Some people have called me a cultural historian, but cultural critics tend to think my emphasis on literary analysis is different from the kind of work they do. I would say that my major intellectual investment is in aesthetics as a distinct shaping force. I think aesthetics have an unusual capacity to reorganize worlds in imaginative, unexpected ways, and thus to take cultural formations and reshape them in aestheticized versions. This probably has some connections with your question about the virtual: I remember when I was writing American Catholic Arts and Fictions, I was not interested so much in dogma or theology as substantive categories, nor in popular works that simply recycled such assumptions, but rather in the way such ideas have informed certain kinds of imaginative reconstruction of the world. I think this can have a progressive dimension, in that it effectively deconstructs any unilateral claim to positive truth, which I always find sinister wherever it manifests itself. But my main concern has been to unpack ways in which brilliant works of art introduce a capacity to turn the world on its axis, to help us see culture in all its variants in a different light. I have very little interest in conventional cultural hierarchies, and I am always interested in how popular culture informs so-called "high" culture and vice versa.

One of my own favorite moments in The Planetary Clock is when I discuss how the difficult postmodernist composer Harrison Birtwistle has long been devoted to Tarantino's film Pulp Fiction and to the way Tarantino scrambles time, which is also something Birtwistle does in his own operas. I think modern literary criticism has tended to become too isolated from other cultural formations because of the professionalization methods that became all too familiar in the twentieth-century academic world, from New Criticism onwards. Literary circles in previous centuries were very familiar with adjacent cultural worlds-Alexander Pope knew Handel personally, George Eliot was very conversant with German philosophy and social theory-and I think bringing these worlds into mutual conversation can be beneficial and illuminating on many different levels of reciprocity. Generic hybridity, moving between art history, film, music and literature, might almost be seen as an intellectual equivalent to transnationalism, a method that reilluminates a discrete object so as to open up new horizons, through taking an oblique angle to texts that might otherwise be too locked into dull, reified understandings. But I do agree with Attridge that literature has its own "singularity," and that its aesthetic dimensions shouldn't be reduced merely to sociology or ideology.

T.c.: As you emphasize the work of aesthetics as "a distinct shaping force," I am prompted to ask about your investment in the practice of "critique" in relation to aesthetics. Especially in light of the argument put forward by Rita Felski, in The Limits of Critique (2015) and more recently in Hooked (2020), about the importance of uncoupling aesthetics and critique, in order to recover the affective and affecting power of artworks beyond their critical force. It seems to me that, because you are interested in recovering what is often occluded, you maintain on the contrary a conception of aesthetics as a locus of critique, which distinguishes your work from the proponents of the so-called "post-critical turn."

P.G.: I think it's important to credit Felski for identifying critical problems that followed on from the familiar deconstructionist critiques of American literature that took place in the 1990s, one famous example being Toni Morrison's Playing in the Dark 
(1992) and her radical interrogation of the racial politics of classic American literature. This was obviously driven by an iconoclastic impetus to challenge the canonicity of books like Adventures of Huckleberry Finn, which had occupied a central place in the American cultural imagination, not just in the university, but also high school. It was a way to contest some of the ideas that had been circulated about American literature as received wisdom and to insist, rightly, that issues of race, gender, class and power relations should be given more critical attention in our readings of American literature.

Morrison's work was timely and important, but I believe Felski is right to insist that we should not abandon making the case for literature as books worth reading for the primary pleasure and enjoyment of reading them. I think this is especially important in the twenty-first century, as students have become more reluctant to read at all. Looking back to the 1970s and 1980s, it seems to me that students tended then to read more widely and to see books as a gateway to wider cultural horizons. Now that digital culture has become more ubiquitous, it is almost as though written texts have become a sort of secondary form, a quasi-elitist or marginal mode of cultural production. So if the first thing you say about an enthralling but complex book, for instance Moby-Dick, is that we need to start by deconstructing its power relations, students are unlikely to want to put in the effort of reading it in the first place. From a pedagogical standpoint, then, I think Felski's argument is important, as it compels us to think about ways of showing students and the general public that these books are worth reading and persevering with, even if they are difficult and challenging. One of the drawbacks of her argument, perhaps, is that it becomes too polemical in its determination to make a public intervention with wide impact. This may have led to her book being a victim of its own success. As a critical argument, The Limits of Critique is more nuanced and balanced than the version of it that has subsequently been circulated in the field.

T.c.: Because you mention issues of pedagogy, I would like to go back to the question of teaching in Europe by comparison to teaching in the US and in Australia. Is there something "European" to the study of American literature and what might it be, as opposed to reading and teaching American literature in the US or in Australia?

P.G.: When I worked in the UK, in the mid-1980s and then again from 1994 to 2009, I was involved in the European Association of American Studies (EAAS), where I collaborated quite closely with friends and colleagues such as Heinz Ickstadt and Winfried Fluck. All this was very interesting, but back then EAAS was structured a little bit like the EU itself, with national affiliate societies, and I felt that the weight of bureaucracy sometimes got in the way of the desire to engage in intellectually adventurous projects. The ambition for transnational dialogue sometimes took second place to the desire for equitable involvement of all constituent member states, and even at that time the UK felt a bit set apart. The Journal of American Studies for instance, published by Cambridge University Press, did not regard itself as a European journal of American Studies as such, even though in terms of circulation it was probably the leading journal of American Studies in Europe at the turn of the twenty-first century.

In the UK itself, institutional tensions were perceptible as well. American Studies programmes had developed in the newer universities (Sussex, East Anglia, Keele, Nottingham). At Cambridge, on the other hand, Tony Tanner was still a dominating 
presence, even twenty years ago, after his early death in 1998. The study of American literature at Cambridge when I went there in 1999 was very much informed by Tanner's intellectual agenda, his pioneering curriculum, and his commitment to reading American literature through a very elegant version of New Criticism. Yet Tony was not very interested in the interdisciplinary aspects of American Studies, nor in situating classic American literature within social or political contexts. Oxford, for its part, had just opened in 2001 its new Rothermere American Institute, which was dedicated initially to the study of American history and politics, with the English Faculty debating whether they wanted to be a part of it or not. There was thus a sense in which American Studies in the UK, particularly American literary studies, did not fit easily into any pre-existing institutional model.

I should also say that European American studies programmes stemmed from US involvement in European reconstruction after World War II, through the Marshall Plan, which entailed promoting a certain vision of US cultural and political values. This eventually became in some ways a drawback, since it fostered and attempted to perpetuate a Cold War version of America and American literary history. This tension became particularly visible with the development of transnational and comparative American Studies in the 1990s, which many departments in the UK and the rest of Europe were reluctant to embrace for fear that it would interrupt their funding if they were seen as no longer upholding an exceptionalist vision of the United States and its culture. Their funding rationale was predicated on an assumption of America as an area set distinctively apart, something I think was intellectually dangerous.

In Australia by comparison, the American Studies Association does not have the established status or the historical baggage that many of the European associations have. It also has stronger links with Asian countries, which fits in interesting ways with recent developments in the broader field of American studies, as illustrated for example by Brian Russell Roberts's Borderwaters (2021), a book that pivots on Indonesia and foregrounds an archipelagic approach to American studies.

T.c.: To return to your work, could you tell us more about your current long-term project? What is it about? And how is it going to relate to Backgazing and The Planetary Clock?

P.G.: The Planetary Clock constitutes a continuation of the project of investigating aesthetic representations of temporality from the vantage point of the Antipodes, which I began with Backgazing: Reverse Time in Modernist Culture (2019). Backgazing was also concerned to reassess American authors in relation to wider geographical formations of space and time-there are extended discussions, for instance, of Thomas Wolfe, whose vexed relation to German modernism differentiated his fiction from the more normative parameters of the American liberal imagination, and also James T. Farrell, whose novels in the "Universe of Time" sequence he wrote in the 1950s and 1960s have been badly neglected by critics, in part because Farrell's links with Irish Catholic culture coming out of Chicago put him at odds with the US critical establishment. This should hopefully flow into the long-term project I am engaged with at the moment, which is to write a temporal history of Western culture working backwards, starting at the Victorian period and going back to the eighteenth century, and then the Renaissance and Medieval eras, to show how visions of time in the Western world were impacted by antipodean perspectives. In Hardy's Jude the Obscure, for instance, Jude and Arabella's son, "Little Father Time," is born in 
Australia. Hardy was very interested in ideas of temporality, how they were picked up in an Australian context and brought back in the Victorian public domain.

The general idea is to consider the crosstemporal as an intellectual analogue to the transnational. I argue that whereas the transnational can offer new perspectives on national identity through problematizing enclosed understandings of national space, the crosstemporal elucidates new views on temporality and chronological progression by bringing different historical periods into juxtaposition. Of course period specialists, like specialists in local and national culture, generate a depth of knowledge that is very important. But this can also lead to a blinkered focus that remains oblivious to external spatial pressures or the temporal formations through which past, present and future impact upon one another in sometimes circuitous ways. Australia is a good place from which to consider these spatiotemporal conundrums because its very odd historical time-scheme-Indigenous culture going back 60,000 years, but settler colonial culture a mere 250-introduces incongruities that reflect in interesting ways on how similar incongruities are implicit, but generally occluded, within more conventional Western cultures.

T.c.: To conclude, and since this interview was organized as part of the celebrations of the twentieth anniversary of Transatlantica, I cannot but ask one last question about your relation as a scholar to France, French literature and culture, as well as French theory. I noted in particular that The Planetary Clock begins with a reading of the music of Olivier Messiaen and the films of Éric Rohmer and ends with a meditation on Michel Butor's Boomerang, while including discussions of Lyotard, Derrida, and Baudrillard on the postmodern and the virtual.

P.G.: I am not very fluent in modern languages in general, though I did study classical languages and literature at school, and I also have a smattering of German. But my French is reasonably good-I studied it to an advanced level, and I remember speaking to a Frenchman in a bar in Cannes when I was there on a language course in 1974, who remarked at the end of our conversation that I seemed to have a slight accent that made him wonder if I was not French. That was the high point of my French language expertise, I think, but France has also been interesting to me because of its Catholic culture, which I recognized very early in my life as a possible alternative to English Anglican orthodoxies, in which I have never had much intellectual or emotional investment. American Catholic Arts and Fictions has comparisons of the criminal violence in Flannery O'Connor to the works of Genet, and it analyses parallels between the urban landscapes of Frank O'Hara and those of Baudelaire, so I think that the transnational overlaps between French and Anglophone literatures have always been something I have been interested in. In that sense, at least, The Planetary Clock could be seen in some ways as a kind of sequel to that book, albeit thirty years later! 


\section{BIBLIOGRAPHY}

\section{Selected Works by Paul Giles}

GILES, Paul. Hart Crane: The Contexts of "The Bridge." Cambridge, UK: Cambridge University Press, 1986. (Paperback 2009.)

GILES, Paul. American Catholic Arts and Fictions: Culture, Ideology, Aesthetics. Cambridge, UK: Cambridge University Press, 1992. (Paperback 2008.)

GILES, Paul. Transatlantic Insurrections: British Culture and the Formation of American Culture, 1730-1860. Philadelphia: University of Pennsylvania Press, 2001.

GILES, Paul. Virtual Americas: Transnational Fictions and the Transatlantic Imaginary. Durham: Duke University Press, 2002.

GILES, Paul. Atlantic Republic: The American Tradition in English Literature. Oxford: Oxford University Press, 2006. (Paperback 2009.)

GILES, Paul. Transnationalism in Practice: Essays in American Studies, Literature and Religion. Edinburgh: Edinburgh University Press, 2010.

GILES, Paul. The Global Remapping of American Literature. Princeton: Princeton University Press, 2011. (Paperback 2018.)

GILES, Paul. “Antipodean American Geography: Washington Irving's ‘Globular' Narratives.” The Oxford Handbook of Nineteenth-Century American Literature. Ed. Russ Castronovo. Oxford: Oxford University Press, 2012, p. 11-26.

GILES, Paul. Antipodean America: Australasia and the Constitution of U.S. Literature. New York: Oxford University Press, 2013. (Paperback 2016.)

GILES, Paul. “Antipodean Transnationalism: The Empire Lies Athwart.” American Studies as Transnational Practice: Turning toward the Transpacific. Eds. Yuan Shu and Donald E. Pease. Hanover: Dartmouth College Press, 2015, p. 237-258.

GILES, Paul. "Bernard Smith in Space and Time: ‘The Antipodean Manifesto' Fifty Years Later." The Legacies of Bernard Smith: Essays on Australian Art, History and Cultural Politics. Eds. Jaynie Anderson, Christopher R. Marshall, and Andrew Yip. Sydney: Power Publications, 2016, p. $153-164$.

GILES, Paul. “Antipodean Modernism: The Retrodynamic Arts of Time Management.” Text, Translation, Transnationalism: World Literature in 21 $1^{\text {st }}$ Century Australia. Ed. Peter Morgan. Melbourne: Australian Scholarly Publishing, 2016, p. 115-136.

GILES, Paul. "American Literature and Its Shadow Worlds: Henry James, Robert Louis Stevenson, and Specters of Worldliness." American Literature as World Literature. Ed. Jeffrey R. Di Leo. New York: Bloomsbury, 2018, p. 29-47.

GILES, Paul. “Globalization.” American Literature in Transition, 1990-2000. Ed. Stephen J. Burn. Cambridge, UK: Cambridge University Press, 2018, p. 233-248.

GILES, Paul. American World Literature: An Introduction. Hoboken: John Wiley \& Sons, 2019.

GILES, Paul. Backgazing: Reverse Time in Modernist Culture. Oxford: Oxford University Press, 2019. 
GILES, Paul. "Reorienting the Transnational: Transatlantic, Transpacific, and Antipodean." The Routledge Companion to Transnational American Studies. Eds. Nina Morgan, Alfred Hornung, and Takayuki Tatsumi. Abingdon: Routledge, 2019, p. 31-40.

GILES, Paul. The Planetary Clock: Antipodean Time and Spherical Postmodern Fictions. Oxford: Oxford University Press, 2021.

\section{Other Works Cited}

ATTRIDGE, Derek. The Singularity of Literature. London: Routledge, 2004.

BERCOVICTH, Sacvan. The Puritan Origins of the American Self. New Haven: Yale University Press, 1975.

EDWARDS, Brian T. After the American Century: The Ends of U.S. Culture in the Middle East. New York: Columbia University Press, 2015.

EDWARDS, Brian T., and Dilip Parameshwar GAONKAR, eds. Globalizing American Studies. Chicago: University of Chicago Press, 2010.

DIMOCK, Wai Chee. Through Other Continents: American Literature across Deep Time. Princeton: Princeton University Press, 2006.

FELSKI. Rita. The Limits of Critique. Chicago: University of Chicago Press, 2015.

FELSKI, Rita. Hooked: Art and Attachment. Chicago: University of Chicago Press, 2021.

GILROY, Paul. The Black Atlantic: Modernity and Double Consciousness. Cambridge, MA: Harvard University Press, 1993.

GLISSANT, Édouard. Le discours antillais. Paris: Gallimard, 1981.

GROSSBERG, Lawrence. "On Postmodernism and Articulation: An Interview with Stuart Hall." Journal of Communication Inquiry, vol. 10, no. 2, 1986, p 45-60.

GROSZ, Elizabeth. "Criticism, Feminism and the Institution: An Interview with Gayatri Chakravorty Spivak.” Thesis Eleven, vol. 10-11, no.1, 1985, p. 175-187.

JEFFERSON, Thomas. Writings. New York: The Library of America, 1984.

LEWIS, R.W.B. The American Adam: Innocence, Tragedy, and Tradition in the Nineteenth Century. Chicago: University of Chicago Press, 1955.

MILLER, Perry. Errand into the Wilderness. Cambridge, MA: The Belknap Press of Harvard University Press, 1956.

MORRISON, Toni. Playing in the Dark: Whiteness and the Literary Imagination. New York: Vintage, 1992.

PRATT, Lloyd. Archives of American Time: Literature and Modernity in the Nineteenth Century. Philadelphia: University of Pennsylvania Press, 2010.

PECKHAM, Robert. “The Chronopolitics of COVID-19." American Literature, vol. 92, no. 4, 2020 , p. 767-779.

ROBERTS, Brian Russell. Borderwaters: Amid the Archipelagic States of America. Durham: Duke University Press, 2021.

ROUDEAU, Cécile. "How the Earth Feels: A Conversation with Dana Luciano." Transatlantica 1| 2015. journals.openedition.org/transatlantica/7362. 
SMITH, Bernard. Modernism's History: A Study in Twentieth-Century Art and Ideas. New Haven: Yale University Press, 1998.

SMITH, Henry Nash, Virgin Land: The American West as Symbol and Myth. Cambridge, MA: Harvard University Press, 1950.

TANNER, Tony. The Reign of Wonder: Naivety and Reality in American Literature. Cambridge, UK: Cambridge University Press, 1965.

TANNER, Tony. Scenes of Nature, Signs of Men: Essays on Nineteenth and Twentieth-Century American Literature. Cambridge, UK: Cambridge University Press, 1987.

TANNER, Tony. The American Mystery: American Literature from Emerson to DeLillo. Cambridge, UK: Cambridge University Press, 2000.

WEINSTEIN, Cindy. Time, Tense, and American Literature: When Is Now? Cambridge, UK: Cambridge University Press, 2015.

WEINSTEIN, Cindy, ed. A Question of Time: American Literature from Colonial Encounters to Contemporary Fiction. Cambridge, UK: Cambridge University Press, 2018.

\section{NOTES}

1. I wish to thank Professor Giles for his gracious response to our invitation to be a part of this special anniversary issue of Transatlantica. I also wish to thank Marietta Kosma for her help with the transcription of the interview.

2. Classic studies from the "Myth and Symbol" school include Smith's Virgin Land and Lewis's The American Adam.

\section{AUTHORS}

\section{THOMAS CONSTANTINESCO}

Sorbonne Université

\section{PAUL GILES}

Sydney University 